\title{
Figures, Diagrams and Table
}

\section{FigURES}

2.I Female witnesses are sworn in, in Lhoknga

2.2 An underage orphaned heir and his female guardian are verified by the mobile sharia court

3.I The judges of the civil judiciary examine a dispute

3.2 The Civil Court of Jantho

3.3 The Mahkamah Syar'iyah of Jantho

5. I A billboard banning khalwat as the devil's way to fornication 93

6. I A land document belonging to the defendant Gani $\quad$ I I 3

6.2 The defendant Gani pointing to a blueprint map I I 4

7.I Mediation and legal skills training for village leaders $\quad$ I39

8. I The judges of the Sharia Court in Aceh hear a case of inheritance $\quad$ I 57

9.I A handwritten document detailing a decision by village leaders

\section{DiAgRAMS}

I.I Menski's kite model

2.I The sources of law and the hierarchy of regulations in Indonesia 44

7.I Extending the principle of the substitute heir to collateral relatives

TABLE

4.I Regulations on liquor in Aceh and Indonesia 